and four administrators, all with equal status except that the senior acted as the head. They were appointed for life on the nomination of the Minister and had executive powers. They had been described as the eyes and ears of the Minister himself. Their duties included special missions-for example, to investigate a severe local epidemic of poliomyelitis or to go to a colony to unify its medical services with those of metropolitan France. Each year they conducted an inquiry into a subject of current importance; in 1948 they inquired into the organization of public assistance, and in 1949 into the care of abnormal children.

\section{Varying Functions}

The five special divisions in the French Ministry were concerned respectively with administration, public health and hospitals, social hygiene, pharmaceutical services, and population. In Belgium the Ministry had two general divisions, one serving hygiene, social medicine, the family and housing, and public assistance, and the other physical education and sport In the Netherlands Ministry of Social Service there were two divisions, one dealing with national and international health, and the other with a miscellaneous group of functions. Great Britain differed widely from the others, one important difference being that the technical people were not intermingled with the others. In Great Britain a system of statutory advisory committees was a quite recent development, arising from the National Health Service. In the other three countries such committees were of great importance and of considerable age. In France there were three such bodies: the Académie de Médecine, the Conseil d'Hygiène (founded in 1903), and the more recent Conseil d'Hygiène Sociale. It was required that all three must be consulted on certain health matters.

In Belgium the two Royal Academies and the Conseil d'Hygiène covered nearly everything in the field of medicine. The Netherlands had a permanent commission with two directors.

\section{Systems of Control and Discipline}

Systems of control and discipline varied considerably in the different countries. In Great Britain the discipline of the medical profession was in the hands of the General Medical Council and to some extent the Royal Colleges. In France the creation of a guild of doctors was much discussed between the wars and was finally brought about in 1945 . It was organized both on a departmental (regional) basis and at the national level. The regional committees had disciplinary powers ranging from the issue of a warning notice to removal from the Register; all their hearings were private. A code of ethics was instituted in 1947. In Belgium the system was similar to that obtaining in France, while in Holland it was somewhat like our own.

In local public health administration outside the central authority the difference between the other three countries and Great Britain could be summed up by saying that in the former the arm of the central authority was extended over the country in the shape of prefects; in the older and larger towns the medical officer of health was a State employee. The position was somewhat similar to that which obtained in the United Kingdom during the war when there were regional commissioners with their officers. The public health administrative units in France were the department (county) and the commune (municipality). As many of the departments in France were too small to have their own service there was a strong tendency to revert to the regional organization inaugurated by Marshal Pétain. In Belgium and Luxembourg the set-up was much the same. In Holland it was more like our own, and there was great scope for initiative. The major difference was the absence of the sanitary inspector. It was strange to find health visitors dealing with reported nuisances and bad housing. He felt that a health service without sanitary inspectors was like an army without sergeant majors.

To sum up, it could be said that in all four countries the actual work done was very similar. Perhaps the most striking difference between the other countries and Great Britain was in the status of the medical officer of health; who in this country was usually a whole-time specialist, but elsewhere was a local-authority employee only, as a rule, in the larger towns, where he was often a part-time clinician; in the rest of the country he was a civil servant.

\section{Training of Public Health Officers}

Time did not permit Dr. Goodman to make many comments on the hospital or specialist services. Maternity and child welfare and tuberculosis control in Belgium were almost entirely in the hands of national voluntary organizations, very heavily subsidized by the State but not controlled in any way.

With regard to the training of public health medical officers, the instruction of medical students was comparable in all four countries, though he had the impression that it was perhaps more thorough on the Continent than in at least some schools in Great Britain, where the amount of time devoted to public health varied greatly. In postgraduate instruction in public health there was, of course, in this country the training for the diploma, whereas in the other countries it was only quite recently that any uniformity had been achieved in the medical schools in this respect. In the Netherlands such postgraduate instruction was only beginning this year. On the other hand, the creation of a national school of public health in Paris in 1947 , combined with the alarming fall in the number of D.P.H. students in this country since 1948, made it appear that we might be in danger of losing our long-standing lead in public health training.

In conclusion Dr. Goodman said that each of the Western Union countries had good and less good points in its public health system, and each had certainly something to learn from the others. The convergent development aimed at in Western Union countries by the Brussels Treaty could be achieved in public health only if they began by knowing something about the organization in the other countries.

\section{Nova et Vetera}

\section{A MEDICAL CONTRACT FROM THE EIGHTEENTH CENTURY}

A typical feature of the English Poor Law Administration of the eighteenth century was the system of "contracting" or "farming out the poor," as it used to be called. The contract was as a rule given by tender. The contractor undertook either the whole administration of the Poor Law for the parish or, more frequently, only parts of it-for example, the administration of the workhouse or the removal and transport of such paupers as did not belong to the parish in accordance with the Act of Settlement. Following this general pattern, churchwardens and overseers of the poor often made a contract with the local general practitioner for the medical treatment of the needy. These contracts, too, were often given by tender.

The appointed doctor became responsible either for all the poor living in the parish or only for those who belonged to the parish; in the latter case he could charge extra fees for the casuals. Some parishes paid per head or for services rendered. The contract usually included the provision of medicines; occasionally a special contract was made with the apothecary. The system of making contracts became popular because it was thought to offer an opportunity for reducing expenditure and cutting down the poor rate. The whole system, however, was bound to lead to frequent abuses, the medical contracts making no exception. Sidney and Beatrice Webb (1927) have described in detail the disadvantages and abuses of the system.

My attention has been drawn to a medical contract found among the parish records of Poulton-le-Fylde (near Blackpool) which runs as follows: 
January 28, 1722/3

Agreed by Doctor Green of Doncaster and Nathaniel Cartmel, Overseer of the Poor of Poolton.

The said Doctor Green agrees to cure John Eves of a fistula and all other distempers.

The said Nath. Cartmel agrees for that cure to pay to the said Doctor Green two Guineas, one now in hand and the other when the cure is perfected.

Received January $281722 / 3$ for the use above mentioned the sum of one pound one shilling by me.

(signed) Edward Green.

There is evidence to show that Dr. Green was an itinerant quack to whose repertory the curing of fistulas belonged. I am much obliged to Mr. G. S. Millner, chairman of the Preston Historical Society, for the following information. In 1695, one Edward Green from Yorkshire, apprentice to Roger Gately, surgeon, complained to the Justices of the Peace in Middlesex that his master did not teach him surgery, but, being a mountebank, "kept a public stage" and compelled him to be a "rope-dancer, tumbler, and jack-pudding." After a careful consideration the Justices discharged Green from his apprenticeship (Dowdell, 1932). This decision, being regarded as an important test case regarding apprentices bound to surgeons, was quoted in legal textbooks in the eighteenth century (Burn, 1780 ; Bott, 1793). According to Burn, Green, after his discharge, "set up the trade of mountebank hinself." Among the Charity Papers of John Hornby (1643-1708), of Newtonwith-Scales, near Kirkham, Lancashire, is a handbill from the end of the seventeenth or early part of the eighteenth century in which it is announced "that to this place [Preston or Kirkham] is come Edward Green of Doncaster, Operator and Oculist," who recommended himself for the cure of a long and colourful list of diseases such as "Cancers, Hairlips, Strangury, Spitting of Blood, Ague of all sorts, Dropsie, Greensickness, Scald-heads, Leprosie, Bloody-Flux, Fistulas, French Pox, Kings Evill, Scurvy, etc." Green stated proudly that he "had a stage erected in 1698 in the Famous University of Oxford." There seems to be little doubt that the Dr. Green mentioned in the contract in 1722 is identical with the mountebank Green.

One does not know whether or not medical contracts based on payment by result were frequently made. They were undoubtedly known for a long time. Hampson (1934) has reported three such contracts from Wisbech. In the first, made in 1597, one Henry Edmunds was promised " $10 /$ yf he doe heale the said sore leg viz in hand $3 / 4$; upon the lyking of the Healing $3 / 4$; and upon the full Healing $3 / 4$; and yf it be lyked well to give more." In 1678 it was agreed "that Mr. William Clarke shall have $£ 3$ for the curing of the Legg of old Bennit, and in case hee make a perfect Cure of it then to have it made up Five Pounds." The third contract, made in 1697, did not allow any payment in advance. It was agreed "Dr Daves to have three pounds for cureing Winterton of his Fits, out of which the said Mr Daves is to pay for all Medicines. Mr Daves to be paid three months after the Cure be perfected; if he make no cure to have nothing either for judgment or Medicines." Miss D. Marshall (1926) has reported a similar contract of the eighteenth century from Burton-on-Trent; in it no details are given about the condition to be cured. It is only stated: "At a vestry meeting it was agreed to give Mr. Gills the sum of $£ 10$ for the cure of Jacob Mosley the younger, in case he shall make him sound and well, so as to be able to work at his trade and get his living. No cure no pay. The money to be paid three months after he shall be reported cured."

There is no record to show whether Dr. Green succeeded with the cure of the fistula and received his second guinea. One case at least is recorded in which the money had to be given back. J. Hammond (1897) has quoted from the churchwarden's accounts of St. Austell (Cornwall) the following entry: " 1709, By cash returned by Mrs. Burden for not curing Creppers head 1-1-0."

Professor Sigerist (1950) has recently pointed out that it has become necessary to extend the scope of research in medical history. Local history documents provide material for the study of the social background of medicine. This material has been little used so far by the medical historians.

\section{A. Fessler, M.D.}

\section{REFERENCES}

Bott, E. (1793). Decisions of the Court of King's Bench upon the Laws relating to the Poor, 3rd ed. rev, by F. Const. London

Burn, R. (1780). The Justice of the Peace, and Parish Officer, 14th ed. London. Dowdell, E. G. (1932). A Hundred Years of Quarter Sessions. The Government of Middlesex from 1660-1760. Cambridge.

Hammond, J. (1897). A Cornish Parish. London. Quoted by D. Marshall (1926).

Hampson, E. M. (1934). The Treatment of Poverty in Cambridgeshire, 15971834. Cambridge.

Marshall, D. (1926). The English Poor in the 18th Century. London.

Sigerist, H. E. (1950). British Medical Journal, 1, 1424.

Webb, S, and B. (1927). English Local Government : English Poor Law History : Part I. The Old Poor Law. London.

\section{Preparations and Appliances}

\section{AN AID TO INTUBATION}

Dr. W. N. VellacotT, senior registrar, Department of Anaesthetics, West Middlesex Hospital, writes: One of the minor irritations which have beset me when intubating under direct vision has been the occasional tendency of a large floppy tongue to hang down over the right side of the laryngoscope blade. This may both decrease the view of the larynx and obstruct the easy passage of the tube. A small alteration may be made with advantage, it is thought, on both the Magill and the Macintosh type of laryngoscope. A narrow metal shelf is added to the right border of the blade to hold up the right edge of the tongue. In the Magill type this shelf is quite flat, any downward curve being carefully avoided; in the Macintosh type the shelf simply widens the existing blade. This addition does not, as may seem likely, traumatize the faucial pillars, provided reasonable care is taken.

In both models the shelf starts $1 \frac{3}{8}$ in. $(3.5 \mathrm{~cm}$.) from the tip, and is itself $2 \frac{3}{8}$ in. $(6 \mathrm{~cm}$.) long. In the Magill type it widens the blade to a total of $\frac{7}{8}$ in. $(2.2 \mathrm{~cm}$.), or to 1 in. $2.5 \mathrm{~cm}$.) if preferred, at its widest point ; to the Macintosh blade, having its own method of disposing of much of the tongue, a narrower shelf is fitted, an additional $\frac{1}{4}$ in. $(0.6$ $\mathrm{cm}$.) being sufficient.

In the case of the Macintosh laryngoscope the metal for the shelf must be produced from some outside source. In ce rta in laryngoscopes of the Magill pattern, however, the metal may be provided from the blade itself. Fig. 1 shows the normal aspect from below, and the dotted line indicates metal which

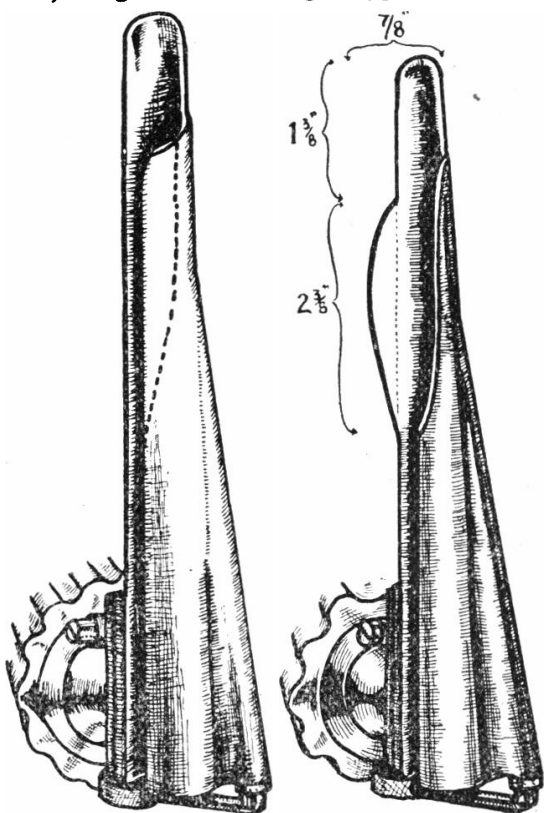

FIG. 1:
FIG. 2. may, in most models, be removed and reshaped for the shelf. This alteration is an advantage in itself, as it provides more space for the passage of the tube; this has been recognized by several designers of laryngoscopes, and is embodied in the more recent Forreger model. Fig. 2 shows the final result from below. The mechanical side of this alteration seems to cause no difficulty to any hospital engineer. 